\title{
Report
}

\section{An Analysis on the Pedagogy and Assessment of Transversal Skills in Vietnamese Technical and Vocational Education and Training (TVET)}

\author{
Ho Thi Hanh Tien", ", Ho Thi Ai ${ }^{2}$, Tran Thi Quynh Nhu \\ ${ }^{1}$ School of Languages and Tourism, Phu Xuan University, Hue City, Viẹtnam \\ ${ }^{2}$ Faculty of Economics, Foreign Languages and Tourism, Hue Industrial College, Hue City, Vietnam \\ Email address: \\ Tien.ho@pxu.edu.vn (H. T. H. Tien), htai@hueic.edu.vn (H. T. Ai), ttqnhu@hueic.edu.vn (T. T. Q. Nhu) \\ ${ }^{*}$ Corresponding author
}

\section{To cite this article:}

Ho Thi Hanh Tien, Ho Thi Ai, Tran Thi Quynh Nhu. An Analysis on the Pedagogy and Assessment of Transversal Skills in Vietnamese Technical and Vocational Education and Training (TVET). International Journal of Vocational Education and Training Research. Vol. 6, No. 1, 2020, pp. 1-10. doi: 10.11648/j.ijvetr.20200601.11

Received: July 18, 2019; Accepted: October 30, 2019; Published: January 13, 2020

\begin{abstract}
This paper that is drawn from a research as a country report funded by UNESCO explores how transversal skills (T.S) are integrated in the curriculum of Technical and Vocational Education and Training (TVET), focusing on teaching and assessment of T.S and its factors influencing practices at four vocational colleges and schools and a tourism enterprise in Central Vietnam. Drawn upon the classroom and workshop observations, interviews of leaders, teachers, supervisors, and staff, and documentary analysis, this research aims to set alight of teaching and assessment of T.S and give suggestions to stakeholders. Findings show although T.S being imparted in Vietnamese TVET schools, teaching, learning and assessment activities of those skills are not really effective. Additionally, no specific policies or frameworks for T.S in Vietnam have been developed. Therefore, closer collaboration and exchange between TVET institutions and industry should be fostered with flexible career pathways and trainers in such institutions should work temporarily in companies to update their vocational competencies.
\end{abstract}

Keywords: Transversal Skills, TVET, Vietnam, Teaching and Learning, Assessment

\section{Introduction}

Transversal Skills are the key to job recruitment, and a prerequisite for young workers to new working environments apart from competences, working capacity or professional ability. According to UNESCO, T.S is the necessary skills for the job's application and retaining which involve a wide range of skills needed for work and environments. Such T.S include problem-solving, communications, creativity, management and entrepreneurial capabilities [1]. In different circumstances and countries, T.S is refined to be associated with various skills such as soft skills, core skills, key skills, generic skills, core-curricular skills, or employability skills $[2,3]$.

Like Malaysia and Singapore, in Vietnam, T.S is popularly known as soft skills or life skills which have been referred as the most popular and widely used term $[4,5]$. This term related to language use, socialized ability, the attitudes and behaviour applied in the communication between people. Some skills can be considered soft skills such as: communication skills, teamwork skills, leadership skills, public speaking skills, conflict solving skills, understanding and empathizing skills, negotiation skills, sale skills, team building skills, influencing skills, listening skills, and wisely refusing skills [4].

There is little research on Vietnamese TVET which contributes to the international literature [6]. Teaching T.S has not widely been applied in the Vietnamese education system. Particularly, the assessment of those skills seems to be neglected. Drawn on the observations, interviews with stakeholders and curriculum analysis, this research examines how T.S is taught and assessed in TVET and which factors affect the practices of those skills. Specifically, in the background of the research report, pedagogies, assessment, 
supporting policies, and perceptions of leaders, teachers, supervisors, staff and students on T.S are explored. This paper additionally highlights the awareness of the importance of T.S teaching and assessment to the stakeholders.

This paper firstly introduces the national context, TVET school policies, and practices related to T.S. It then discusses pedagogies, assessment and perception of TVET stakeholders. It finally concludes with the policy suggestions for stakeholders.

\section{Background of Transversal Skills in Vietnam}

Since the release of Reform Policy ("Doi Moi") in 1986, Vietnam has experienced significant economic growth, shifting the employment from the agriculture sector into higher productivity in industrialized sectors [7]. The national modernized and industrialized economy involves a change in workforce demands. However, Vietnam has faced critical challenges. One of the main challenges is related with its poor workforce quality and low productivity, specifically the paucity of employee's relevant skills and their limited access to improve the required skills (i.e. transversal skills) [8].

Vietnam currently has an abundant workforce. However, its quality of the labour force is low in comparison with other countries in the region. According to a report on Labour Market Information Statistics in Vietnam at the first quarter of 2018, among 54 million employed labourers, there are only about 23.6 million of them spending at least 3-month training or owning a diploma or degree (General Statistics Office - [9]). The employment generation has been considered rather weak in Vietnam compared to the changing rate of economic expansion, [10]. The above report reveals the significant skills mismatches and the relevance of TVET [11]. Moreover, Vietnam's labour productivity in 2017 was among the lowest in Asia although there was a growing signal, according to a recent report published [12]. Specifically, according to GSO, the 2017 Vietnam's labour productivity is ranking only $1 / 3 \mathrm{rd}$ of Thailand and China, 1/16th of Malaysia and 1/18th of Singapore [13]. Those figures have created a push to improve the quality of labour force in the integration era of Vietnam. Despite the recent improvement in skill training in Vietnam, the vocational quality has not yet sufficiently satisfied the market needs in terms of professional skills, and soft skills; for example, industrial working capabilities, team-working. It is the fact that "more graduates have not been equipped with the skills needed for work nor have they sufficient knowledge for the society" [14]. Thus, compared to other countries, these limited skills and competencies have resulted in a large skill gap in Vietnamese workforce quality [15].

Policy and Transversal Skills Integration

While dealing with the skill gap between workforce quality and the inevitable changing demand of the industry, several actions and decisions have been made by the Government in vocational training. On December 30th, 2011, the Ministry of Education and Training (MOET) issued Circular No.
$66 / 2011 /$ TT-BGDĐT on the course curriculum on communication skills in the training program at the technical secondary level [16]. Since then (2012-2013), communication skills have been taught in schools as the elective module with 2 credits [16].

In order to improve life skills activities, MOET also issued Circular No. 04/2014/TT - BGDDT dated February 28th, 2014 which regulated the management of Life Skills Education and extra-curricular activities [17]. However, there have been no formal and clear written guidelines for vocational training under the management of the Ministry of Labour, Invalids and Social Affair (MOLISA) or other ministries (i.e. Ministry of Transport), on teaching Soft Skills (transversal skills) in the vocational training institutions. In that context, in order to close the distance between vocational knowledge and working skills, there should have some trainings for students from the perception of vocational leaders [4].

Since the Government made decisions on public education and training, more action plans should be considered to reduce the distance between manpower and industry. Yet, to prepare a skilled workforce for the rapidly changing economy, many actors such as employers, educational institutions, students and the like are also responsible for changes in skill development [18].

\section{Research Design}

The qualitative approach that mainly includes observations, interviews, and document analysis techniques is applied in this research as it provides a thick description of the research's issues [19]. Teaching and assessment of T.S such as communications skills, collaboration skills, and problem-solving skills at 4 vocational colleges and 1 tourist enterprise in Central Vietnam are investigated. These research sites taking charge of providing manpower for Central Vietnam - an emerging industrial area represent for major fields, including medicine, transport, tourism, and industry.

TVET curriculum frameworks, national and institutional development plans, strategies and policies on T.S are examined in this research. Additionally, 4 observations at classrooms and workshops at each research site are carried out to see how T.S is delivered and assessed. Semi-structured interviews including 2 teachers or supervisors and 2 leaders (1 leader of the training department who takes charge of training, curriculum allocation and 1 leader who manages all activities and proposes strategies and plans) are applied. The research findings reveal in the observation and documents are supported for validity in the interviews.

All data collected are coded (i.e. CL1: College 1; T: teacher, EN: Enterprise). Codes are analysed according to themes such as pedagogies, assessment, and policy suggestions.

Ethic consideration is also concerned when doing this research. The information sheet about the research is provided for all participants in order to ensure that they understand the purpose and their rights voluntarily taking part in this research. 
This research is limited to exploring TS teaching and assessment in Central Vietnam. Therefore, generalising the proposals and findings to T.S in Vietnam is difficult without making subjective judgments. However, it is acknowledged that the practices of T.S in regions with their own economic focus may slightly vary from Central Vietnam where the research is conducted.

\section{TVET Policies and Practices of Transversal Skills in Vietnam}

According to the UNESCO 2014 report on policy implications, one of the initial considerations into teaching transferable skills in TVET is how best to incorporate them into the curriculum [20]. Currently, there are three models of integrating T.S into curriculum applied by the stakeholders of each country. Firstly, specific subjects include a well-defined entity within the formal curriculum such as a subject with specific goals and syllabuses for formal teaching. Secondly, cross subjects run across, infiltrates and/or underpins all "vertical subjects" (i.e. traditional school subjects). Lastly, extra-curricula make parts of school life and embed purposefully in all types of non-classroom activities. The differences between these three models are their delivery. While the first model is officially delivered with a curriculum framework and obviously recognised as a subject, the other models are imparted cross other core subjects and extra activities. For example, the subject on first aid techniques, communication skills with patients are also inserted in lessons. It doesn't exist a separated subject or training program. As a result of vague policy guidelines, implementation of T.S in TVET leaves rooms for improvement [20]. The school policies and practices in T.S meet these definitional, operational, and systematic challenges.

In the definitional challenge, there is a lack of clarity in the scope as well as the desired outcomes of the teaching transversal competencies [21]. The operational one could be accounted for an additional burden on teachers, the lack of assessment mechanisms, incentives, budgets and the insufficiency of teaching/learning materials and teaching guides, and teachers' capacity. The systematic one also involves the challenges such as large class sizes, overloaded curricula, pressures to achieve academic success, inconsistency with high-stake exams, lack of understandings among parents and other stakeholders, and overall school/community cultures.

\subsection{Reflection of the Policies on Transversal Skills at Colleges}

Being aware of the important roles of T.S in the workplace, these skills as communication skills have been decided as an official subject. Other skills such as collaboration skills, and problem-solving skills have been crossed into all the subjects for the branches of learning such as Nursing, Physiotherapy, Occupational Therapy, etc. at some colleges since 2010 (I.T 1.CL2). These subjects such as Physiotherapy Profession \&
Basic Processes, Behaviour and Social Research, and Effective Communication in Health Care Relationship often take from 2 credits to 3 credits in each program.

According to the report of policy implications in T.S in TVET [20], there are several practical approaches for teaching transferable skills in TVET ranging from, at one end, integrating them into separate theoretical subjects for, at the other end, teaching them as partially or fully integrated into practical subjects. The development of T.S is also shown in the activities organised by Youth Unions, and academic integrated programs that students study both social and specialised knowledge with T.S (I.LD1. CL1. CL3). There has been an increase in the competitions related to T.S which are held by the college itself and other colleges. For example, at some colleges (CL1, CL2\&CL3), TS evaluation respectively includes in the vocational skill competitions or nursing practice sessions. This evaluation is differently conducted in sites. For example, colleges often evaluate students' T.S through daily lessons, mid-term tests and final tests whereas EN evaluates their staff's T.S through observation and monthly or yearly written tests. Although assessment methods can be beneficial for awareness raising and benchmarking at sites, this evaluation has not largely developed yet. It is difficult to incorporate them into the curriculum frameworks (I.T1). The reason is that teaching T.S is strongly encouraged in all subjects. It means that most of the colleges require their teachers to integrate teaching T.S in each lesson. Teachers foster their students with T.S and specify in their teaching objectives while designing in their lesson plans without having specific written policy guidelines from the managing board. That means teachers have to self-study and design the lesson plans that are suitable for their teaching context and students' levels (CL1, CL2, CL3, CL4).

\subsection{Supports from the Managing Board}

A significant challenge is a clear guideline on TVET policy about teaching requirements and innovative teaching methods. Those requirements are reminded to bring them into practice in specialized quarterly meetings by the managing board at colleges. TVET teachers feel comfortable with traditional teaching and resist changing their pedagogical practices to foster students' transferable skills. To help them adapt to changes, leader boards should focus on: (1) teacher training, (2) selection criteria, (3) training material, and (4) awareness raising among all school staffs [20].

The findings revealed that the managing board pays prompt attention to teacher training and materials because the teachers will not be able to successfully integrate T.S into their lectures without supporting policies from the managing board (I.LD2.CL3). At other colleges, an increasing consideration in T.S from the managing board is revealed (I.LD1.CL1). Training programs on T.S teaching have been organized for teachers in four colleges in recent years (I.LD1.LD2) and a tourist enterprise (I.LD5.SP.EN) such as taking part in workshops or seminars on applying T.S in teaching and working, methods of imparting T.S into lessons. However, it depends on the policy of each college or enterprise. There are 
not any official guidelines from the Ministry of Education and Training for T.S teaching. The managing board should encourage their staff to develop and apply innovative teaching methods. The teachers are supported to attend some IT training courses in accordance with Microsoft standard (MOS) to increase the working productivity and support students as well (I.LD1.CL1). Besides, sending teachers to some foreign countries to participate in training courses is an effective way of equipping the skills and knowledge for teachers (I.LD2.CL3, LD1.CL1).

The selection of staff for teaching T.S integrates into the subjects only based on their teaching experience and professional capacity. It is difficult to organize a contest for selecting qualified staffs in transversal competencies (I.LD1.CL4). However, through the results of the national good vocational contests for vocational teachers/students (I.LD1.CL3) and the numbers of the teachers attain the international certificates such as TOEIC in English and MOS in IT (I.LD1.CL1) school principals can assess how their teachers learn and teach T.S. They are believed these skills are necessary for staff and students in their future careers. It is reflected the current needs as professional skills for all people who seek for a job.

In the school planning and teaching process, the teachers' abilities and implements depend on their experience and expertise. This report on applying T.S at vocational colleges in Vietnam shows that there are about $30 \%$ of teachers who could impart T.S in the subjects and program (I.LD2.CL3). Even only the teachers who have at least 10 years of teaching experience can be chosen to teach T.S (I.T1.CL2). The teachers themselves must self-study and/or share experience from their colleagues in the T.S teaching both communication skills and others (collaboration skills and problem-solving, etc) (I.T1.CL3). One teacher interviewed stated that communication skills and collaboration skills are often imparted flexibly in theoretical lessons and practical lessons (O.T2.CL3).

From a different approach, training and recruitment staffs at the enterprise are always from observation of their employees with feedback and direct advice. Staff takes part in the training courses in T.S including Communication Skills, Negotiation Skills, Customer Service Skills, and exchange with other enterprises in the region and the neighbouring provinces (I.LD.EN; SP.EN). The staff is usually trained by specialists from famous universities and hotels in Vietnam or in Thailand. Additionally, the leaders or experienced staff will train others. However, they face the difficulty of the salary payment because employees trained well and professionally in T.S will move to the other working places with a higher salary (I.LD.EN). Although T.S take a total of $30 \%$ in their recruitment criteria they have to take a lot of time to train the employees on how to serve customers professionally (I.LD.EN).

In short, policies, practices and school environment, and supports for teachers play an important part in Vietnamese TVET. They can support and encourage teachers in implementing T.S through teaching methods successfully.
From the findings on policies, practices and school environment, and supports for teachers in T.S, T.S should be applied widely and inserted into the curriculum at most of TVET schools in Vietnam so that TS teaching and learning become more sustainable.

\section{Imparting Transversal Skills in TVET Pedagogy}

This section firstly discusses a brief background of the school environment. Then, current pedagogical practices of T.S are presented in this chapter. It finally examines socio-cultural factors influencing the teaching of T.S because it is believed that there exists a relation of pedagogies with social cultures and supports for teachers in imparting T.S according to Sukhan [22].

\subsection{Teaching Transversal Skills in Vietnam}

Dumont, Istance, and Benavides explain that learning environment plays an important role in teaching and learning. It has effects on the nature of learning and methods of teaching and learning [23]. Hannafin and Land also affirmed that the learning environment reflects some features of the nature of learning, roles of teachers and roles of learners [24]. Thus, it is very essential to examine the learning environment.

\subsection{School Environment}

The research explores T.S teaching and learning at 5 research sites including 4 vocational colleges with 4 different majors (Industry, medicine, tourism, and transportation) and a tourism enterprise in the central area of Vietnam. Therefore, each research site has its own strengths and features. The common features of learning and teaching at these colleges are at classrooms and workshops. Classrooms are arranged with desks and chairs in rows for theory delivery. Practice sessions often occur at the workshops, which are equipped with teaching facilities, models, machines and tools. Interestingly, some workshops are divided into a theory section (desks and chairs are arranged in rows) and a practice section (O.CL1, O.CL2, O.CL3). Students often undertake their first period for theory explanation, then, do the practice afterward.

The learning environment of the enterprise is different. Most of teaching and learning are happened in the meeting rooms and at the office during the direct contact and consultation with customers. It is the real-world learning environment supporting learners to improve their skills and knowledge effectively.

\subsection{Pedagogy}

The current TS pedagogical practices at the research sites are in a variety. T.S at all colleges is inserted in an official curriculum framework, and social and extra-curriculum activities organised by the Communist Youth Union of the colleges. At some colleges, T.S is taught as an elective subject (CL4) students may or may not choose this subject while at 
other colleges, these skills are delivered as a core subject in their official training program (CL1.CL2.CL3). In addition, these skills are integrated into some main subjects and teachers often discuss and guide students on how to apply these skills in their professional skills (I.LD.CL2, I.LD.CL1, I.T.CL3). From the observations, discussions during the lesson or questions and instructions given by the teachers in a lesson of a specialised subject included T.S such as communication skills, and problem-solving skills. The following extract from a lesson observed will provide a clear view of the integration of T.S in professional subjects (See Figure 1). The same results found in the interviews. Teachers reaffirmed that they often insert skills of communication and problem-solving in every professional subject where it is relevant (I.CL1.T2; T1; I.CL2.T2.; I.CL3.T1).

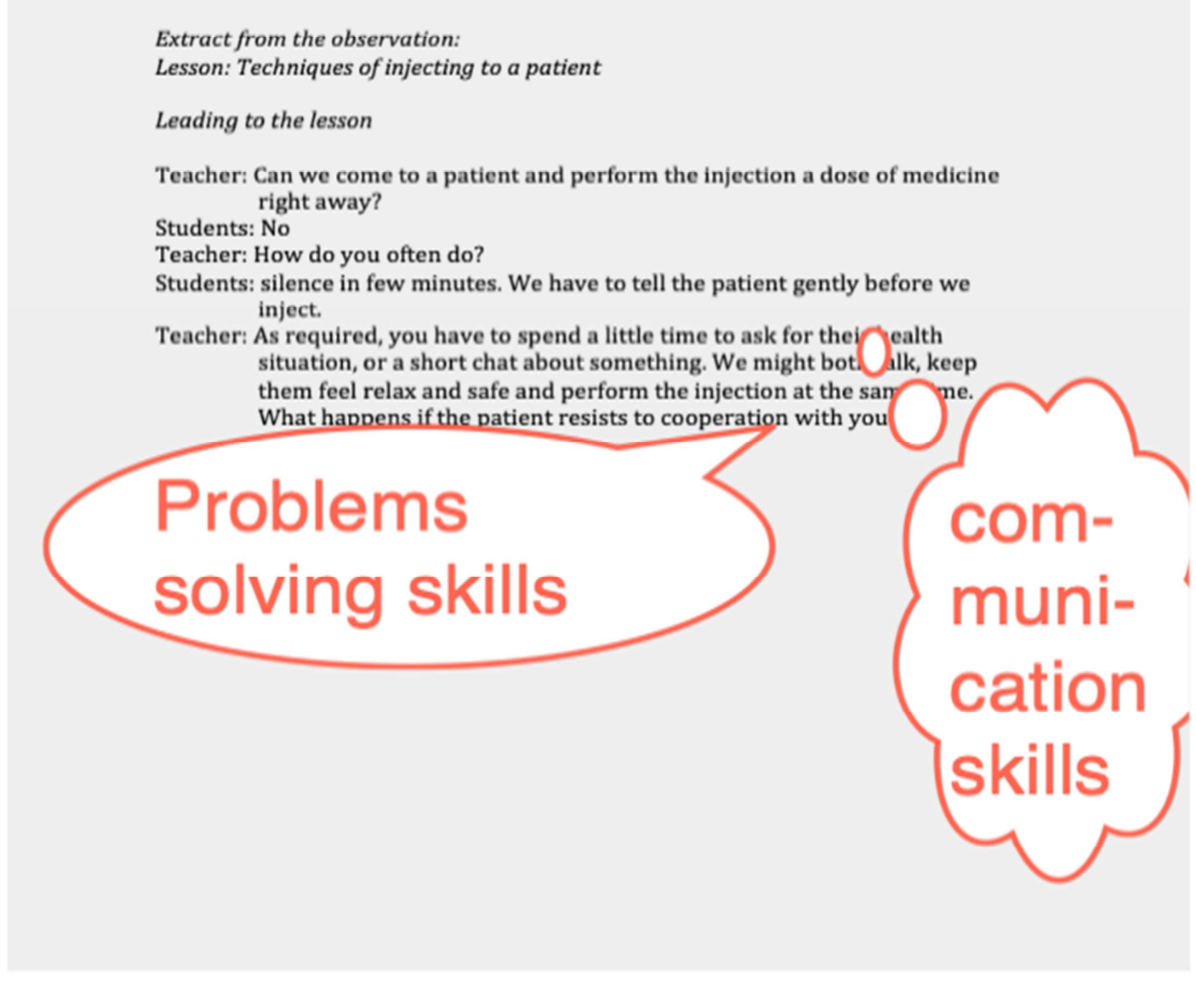

Figure 1. Transversal skills are intergrated in professional subjects.

Nevertheless, each college has its own major professional focuses; this leads to the different applications of T.S. For example, according to the leader and teachers at CL2 and CL3, communication skills are very important for their students to communicate with patients while the problem-solving skills and collaboration skills are not less essential. In contrast, problem-solving skills are very important for technical professions (CL1 and CL4) although the communication skills and collaboration skills are also recognised as crucial ones for students to find a job and be successful in their future. The specific professions likely reflect a different way of integration. However, all colleges reckon the essence of T.S and delivered partly these skills to their students and employees.

According to the curriculum frameworks of the colleges, there is a main or core subject namely "communication skills" delivered in 30 periods for the second-year students. It can be the delivery of T.S at these colleges. As teachers and leaders at interviews shared that it is hard for students to acquire skills and be able to apply them within 30 periods (I.T.CL4, CL3, CL2, CL1, I.LD.CL2). The teaching methods uncovered during the observations and interviews are transmitting knowledge, or theory delivery with some practical periods of group works and presentation (I.T.CL4), similarly found at the college 2 with a theoretical explanation of principles and standards and then practice them (I.T.CL2). It can be interpreted that the methods gradually help to form skills for students (I.T.CL2). Furthermore, communicative teaching methods, exchanging information, giving a presentation, learning by role-playing, learning by doing are dominant uses at some colleges (CL1, CL3). This may depend on their specialists such as tourism, hotel management. Group discussion is also applied in the TS teaching at these colleges; however, the students' participation in those group discussion activities reflects the ineffectiveness because of their passive learning style (O.CL2). The extract in Figure 1 also proved for the unsuccessful group discussion. The efforts to apply a student-centred approach and inquiry-based approach in teaching are discovered during the interviews and observations.

Apart from teaching activities at classrooms and workshops, extra curriculum or outside classroom activities are utilized 
for T.S teaching such as tours to hotels, organising student parties or playing roles at the college's hotel (CL3). These activities offer students a real-world learning environment and improve their knowledge and skills.

The finding reveals the application of ICT in teaching T.S at all colleges. Using ICT to support teachers in teaching such as preparing e-lessons with vivid pictures and photos and communicating with students via emails. Most of the teachers at interviews share their efforts in applying ICT with the purpose to find the best ways for students to acquire knowledge and skills.

T.S Teaching in the enterprise is quite different from colleges. It is not only teaching communication skills, problem-solving skills as the colleges but also relates to specific teaching practices for their profession. They are indicated in the findings that teaching does not happen in a formal teaching environment. Work-based learning approach is applied to the enterprise. Learners are trained through learning by experience, learning by doing, learning from others and self-study (O\&I.EN). This kind of learning is not only for T.S but also for improving specific professional skills for employees at the enterprises. "Direct comments and advice are given through the observation of staff/apprentices", shared supervisors. Additionally, supervisors and trainers often guide learners (staff or apprentices) whenever the office is not crowded with customers. Official training at the meeting room of the enterprise with slides and discussion about communication skills for staff is offered nearly every week (I.SP.EN). Outside activities such as cooperating with other enterprises in sports and music are also provided to bring staff and apprentice an opportunity to share their experience in working and daily life.

\subsection{Influences of Socio-culture Factors in Teaching T.S}

The common feature of all colleges is that students come from different areas in Central Vietnam from the highland to the coasT.Students from different cultures, especially international students from Laos or ethnic groups (using their own ethnic languages) in Vietnam, bring lots of barriers for teachers in imparting T.S such as time consuming to explain for them to understand the culture, social values, and specific norms because of their limited Vietnamese language (I.T.CL2, CL3). Furthermore, the typical characteristic of people in Central Vietnam is timid. This is also taken to the classrooms.

\subsection{Supports for Teachers}

The findings of document analysis and interviews bring to light that there is limited support for teachers who deliver T.S. Most teachers are chosen based on their teaching experience such as 5 or 10 years of experience depending on each research site. Some teachers do not have an opportunity to attend workshops or seminars on how to teach such skills. They all must self-study and share experience with their colleagues.

Staff and apprentices at the enterprise are sometimes sent to other companies for observation, professional development or attending seminars on how to communicate with customers.

In summary, although T.S are imparting into the VET curriculum in Vietnam, teaching and learning of those skills are not effective. Therefore, colleges, organisations and Vietnamese government should have supported such as teachers' training, organising professional seminars and providing a good learning environment for teachers in improving their skills and knowledge to have an effective delivery of T.S.

\section{Assessment of Transversal Skills in TVET}

As mentioned previously, the teaching and learning of T.S at vocational institutions occur in classrooms and workshops. Therefore, the assessment of these skills is similarly performed at those places. There are two types of assessment found in all educational settings. The findings show the theoretical assessment through a paper test and the practical assessment at the end of each semester are often used at all colleges. Specifically, all teachers confirm that students are assessed their T.S by mid-term tests and ending semester tests as other subjects (I.T.CL1; I.T.CL2; I.T.CL3; I.T.CL4). These mid-term tests and end of semester tests are often paper-based and focused on theoretical knowledge. Students are requested to write their answers to the questions given. Marking on how much knowledge students produced and how well they answered in the paper test based on the supposed responses prepared by the test designers is a common way to assess students' skills. The test questions are usually related to or included in parts of the lessons delivered. It aims to check the knowledge of how well they memorised the content delivered by the teachers. It is hard in somehow to evaluate acquired skills by paper tests. From the above description, using a paper-pencil test is considered as the nature of T.S assessment at these research sites. In some colleges, students must spend another practical assessment at the workshops (I.T.CL3; I.CL2). At this stage, teachers based on the checklist with assessment criteria to evaluate students such as "Have communication/explanation of the task proposed to do to the patient"; "Follow the right procedure of first aid support" (I.T.CL2); "Have followed all steps of a hotel receptionist when welcoming a new customer: greeting, offer for help" in a role play situation, or their attitude in performing the task (I.T.CL3). All criteria have followed the regulations or procedures of preparing a test including components of a test: attitude behaviour assessment, performance and skills assessment and grading guideline (i.e. 1 point for 1 criterion or 2 points for 1 criterion depending on the designers).

As the teacher and leader explained, the assessment of T.S is shown in the reports and history of each patient (I.LD.CL2; I.T.CL2). It is argued that those who have good communication skills or problem-solving skills usually gain more information about the disease history of patients when they perform their task of exploring the disease history of patients (I.LD.CL2). This is an example of a specific 
profession to demonstrate a variety of assessment methods applied at the research sites.

Those descriptions can be interpreted as summative assessments that "are given periodically to determine at a particular point in time what students know and do not know" and are "generally used as part of the grading process" [25]. Although the practical assessments are undertaken, feedbacks are not given to students at the end of each assessment. What students often achieve is shown in the grade (i.e. 8 marks or 7 marks) (I.ST.CL2, I.ST.CL1). Such assessment is not formative as William and Leahy define "an assessment is formative to the extent that information from the assessment is fed back within the system and actually used to improve the performance of the system in some way" [26]. Interestingly, apart from those mentioned assessment methods, a part of the formative assessment is believed to be applied at one college where evaluating students through the classroom participation, group-work, and students' real work is used as the measures to assess T.S (I.T.CL3). It is known as a mark of a learning process; that is the students' contribution to this subject in a semester including their attendance, participation in discussion and joining in class activities at the colleges. Except from the mid-term test which counts for $40 \%$ in the total $100 \%$ of the mark for the learning process of that subject, the remainders will be the attendance $(10 \%)$ and $50 \%$ for students' contribution in doing practice task, homework, or doing quiz respectively. This depends on each teacher. One teacher interviewed shared her experience in marking the learning process that she often gave students to do group work for role place situation and marked on their contribution to the situation (I.CL1.T2. I.CL2.T2. I.CL3.T1). The same mark might be given to the whole group as a mark for their good collaboration. In addition, a short writing task was given to students for their assessment of the learning process. The 10-level grading system for this assessment is similar to the midterm test or end of semester test.

The assessment of these skills is performed in other subjects and accounted for $30 \%$ or $40 \%$ of their total grades at some colleges (I.T.CL2, I.T.CL3). The integration and assessment of T.S in other subjects are important for students to gain the required skills apart from their professional skills. The assessment of T.S at the tourist enterprise is different from colleges. There is a variety in assessing staff T.S such as daily feedbacks under the supervision of the team leader, monthly evaluation basing on $\mathrm{A}, \mathrm{B}, \mathrm{C}$ scale, and annual evaluation (I.SP.EN; I.LD.EN; I.SF.EN). It is explained that each office has a different criterion and a monthly test for increasing salary is given to all staff (I.SP.EN). In addition, customers' comments on the enterprise's staff via Trip-advisor website are used as the measures of T.S (I.SP.EN; I.LD.EN). As the leader argued the ill performance of staff who get lots of negative comments reveals a low level of T.S such as unskilled problem solving or communication with customers. Therefore, the leader supposed to provide more TS training for those staff.

From the research findings, the enterprise is applying the formative assessment which is "defined as assessment carried out during the instructional process for the purpose of improving teaching or learning. What makes formative assessment formative is that it is immediately used to make adjustment to form new learning"

Regarding the fairness and validity of the T.S assessment, some teachers and leaders at the colleges think the ways they are applying reveal the genuine results. It is explained that they always carry out the quality assurance and supervision for the assessment (I.LD.CL3). The assessment is often organised at the college level by offices of quality assurance and assessment. It means all the students at the same enrolment year from all faculties will sit in the exam at the same time with the supervision of different teachers (not the teacher who taught these students). Teachers mark papers confidentially without students' names under the supervision of the Office of Quality Assurance and Assessment. However, some other teachers believe that their assessment reflects the students' ability relatively because of many factors such as paper-pen exams believed not to reveal a skilled or unskilled person, and students with good communication skills often get better marks on their practice test (I.LD.CL2, I.T.CL2).

Similarly, the fairness and validity of the assessment is approached to be a high level at the enterprise because it combined both the customers' comments on the website, team leader's supervision and their self-assessment at the end of each month. However, some staff shared that sometimes the supervisors assess one staff basing on their own feeling toward that staff. All leaders, teachers, supervisors, staff, and students think the socio-cultural factor influence the assessment. The example of students in nice appearance and clothes is often achieved a high grade. Students from ethnic groups often have difficulties in communication skills as well as other skills; therefore, such assessment is unfavourable for them.

The research findings show that there is no application of ICT in the T.S assessment at both colleges and the enterprise. In terms of the good practices of assessing T.S, some leaders and teachers address the assessment template including communication skills, presentation skills, and language skills for every practical period should be put into practice. In conclusion, the summative assessment is used in 4 vocational institutions while the enterprise applies formative assessment. Although all research sites effort to bring fairness and validity to the T.S assessment, the results are reflected a relative assessment.

\section{Perception Towards TVET School Practices}

The perception towards TVET school practices is explored through the leaders' views, and the perspectives of teachers and students on the T.S teaching and assessments.

\subsection{Leaders' Views on Teaching and Assessment of Transversal Skills}

Current national policies mentioned in chapter 1 on fostering T.S enable leaders of an educational institution to 
involve in the integration of these competencies into educational practices. Apart from technical competences, students' transversal skills after graduation draw more attention from leaders of vocational schools. According to the result of the project, most principals advocate teaching and learning T.S in their current curriculum. They admit that transversal skills are essential skill packages for students in both working and life (I.CL2.LD1; I. CL2.LD1; I.CL3.LD1). Therefore, transversal skills have been applied to some teaching curriculum. Specifically, according to the project outcome, transversal competencies have been taught for students of technical secondary and college level as the compulsory subjects with 2 credits per subject, namely Communication Skills, Time management skills, Working environment and People, and so on (I.CL1.LD1\&2, I.CL3.LD1). These actions encourage students' learning T.S in class and help them to be ready for the coming working environments.

However, training quality and teacher's qualification upon T.S is a question. Leaders at some colleges share their concerns about the teaching quality that some teachers haven't been trained to deliver transversal skills in class. Teachers give instruction derived from their own practical experience (I.CL2.LD1). Training courses for teachers on T.S have rarely been organized. Moreover, the lack of experience in teaching these skills can account for the issue. Actually, only 30 percent of teachers teaching at the Secondary level can have the capacity to teach T.S apart from their major classes. (I.Cl4.LD1). Those who instruct at the elementary level or short course find it hard to apply transversal competencies during training. Therefore, graduates are not sufficiently prepared to handle issues at work because they are not equipped to do this by their teachers.

Assessment on T.S during practices is determined to evaluate the actual process and identify the gaps between policies and practices at school levels. In fact, skills integrated into other technical majors prevent leaders and teachers from observing and measuring the right nature of the skills (I.CL1.LD2). Assessment on T.S is rather difficult because these skills are not directly related to the main theoretical content of the school's curricula [24]. Although some institutions have applied T.S in their curriculum and assessment, some leaders indicate that the colleges have not set criteria for assessment on T.S (I.CL2.LD1; I.CL4.LD1). That can be explained those institutions managed by other Ministries (not by the MOET) may not apply the guidelines on implementing soft skills or T.S in their curriculum planning. Therefore, the investigation and assessment in accordance with appropriate scoring scales and documentary in the future should be done (I.CL1.LD2).

\subsection{Perceptions of Teachers, Staff, and Supervisors on T.S}

The perceptions of teachers, staff, and supervisors on T.S are discussed through the application and implementation of transversal competences into practices. Beside the positive reviews, some issues are generated and featured as the key challenges; specifically, curriculum implementation, skill assessment, facility support, and practical training.

Curriculum implementation plays the most important part of producing students' outcomes. According to Altbach, the curriculum variety has a certain effect on the quality of students especially their effectiveness after graduation because teaching is structured through programs and courses [27]. Apart from some compulsory subjects on T.S, T.S have been gradually imparted to in other technical subjects. However, in this research, some current curriculum contents cannot provide students with adequate major knowledge and the skills needed (I.CL1.T2). For example, in a technical curriculum of a 2-3 credit subject (30-45 period) (i.e. Welding, Automobile maintenance), teachers are required to cover overall 10 theoretical chapters including practical sections within a limited duration. In the meanwhile, T.S is considered as the elective auxiliary part in the training plan. Therefore, due to the limited teaching duration, training on T.S seems to be ignored. As a result, implementing both curriculum content and transversal competences is impossible (I.CL4.T1). Another challenge that teachers may confront is the lack of effective evaluation methods in T.S. As stated above, although the teachers' awareness of T.S has been currently raised, more attention is still paid to the content of traditional modules. For technical modules with imparted skills, the module assessment seems to focus on the major content rather than the skills. This might lead to difficulties in evaluation of students' T.S among technical majors. To solve this problem, schools ought to train and create an open environment to promote students' active skills. Moreover, students are required to be on longer probation or bound apprentice during school-time for more experience as practical working entirely differs from theory (I.EN.SF2).

Little training and support reduce stakeholders' interest and promotion of the educational change. On one hand, teachers are under the pressure to improve students' practical skills meeting the needs of social change. On the other hand, the workload and rigidity of the technical-majored programs restrict teacher's professional development (I.C14.T1, I.CL2.T1). The leaders seem to focus more on majoring knowledge but limitedly invest in enhancing social and working skills (I.CL4.T1). Therefore, most teachers interviewed desire for further training on T.S and updating teaching methodology.

\subsection{Students' Views on T.S Teaching and Learning}

Transversal competence has become the key target currently as learning products need to be applicable and matching to work performance. However, the overwhelming demands for skilled graduates remain challenges due to the limited learning knowledge and lack of actual practice of real graduates. Being equipped with official T.S in class, some students have raised the awareness of the importance of skills and prepared their readiness for a future job (I.CL1.ST1\& I.CL3.ST1). Students admit that activities and flexible learning such as group work, games, and simulation activities in the class have enhanced their self-confidence in communication, helped to learn from practical situations, and 
improved current weaknesses.

Meanwhile, for some students who have not sufficiently equipped with the T.S through lessons, activities outside classrooms are recommended. Some students reveal that through activities the Youth Union leaders organize, students are promoted to open and flexible learning, cooperation, group discussion and management (I.CL1.ST1). As a result, if learners tempt to improve their T.S, besides skill-imparted modules, such skills can be acquired from extra-curriculum activities (I.CL1.ST1, I.CL3.ST1).

Although vocational colleges in the research sites have initially applied and customised their educational framework, there still face challenges to produce relevant learners' demanding outcomes. Therefore, the situations put the questions toward policymakers and related stakeholders to work out the appropriate solutions.

\section{Policy Suggestions and Conclusion}

This paper examines ways in which T.S is imparted and assessed in TVET in the Asia - Pacific region and particularly in Vietnam. There are no clear national policies or specific frameworks for T.S in Vietnam. Therefore, MOET and MOLISA should provide all the educational systems with the national policies in the T.S teaching which gives priority to generating high levels of knowledge and skills with attention increasingly to more demanding forms of " 21 st century competencies" [23]. Such policies help learning more interesting with the theory reduction and practice focus (I.LD2.CL3).

Although T.S is imparting into the VET schools in Vietnam, teaching and learning activities of those skills are not effective. Upgrading or training TVET teachers with both teaching methodology and technical knowledge and skills should be a plan to be conducted annually to meet the demand of TVET activities suitable to the market economy.

Colleges should flexibly and creatively apply the T.S education in their own school practical conditions (I.ST1.CL3). Objectives, content, the method of training and teaching and learning activities should be innovated to meet the needs of the industrialization and modernization (I.LD.EN). TVET, organizations and the Vietnamese government should support teachers and students at vocational schools with the training programs and working skills and knowledge, the effective delivery of T.S (I.T.CL3) or encourage employees with life-long learning to gain further skills and qualifications in response to the national socio-economic development and the integration of ASEAN (I.SF1.SF2.EN). TVET schools which have traditionally provided vocational skills for finding jobs need to pay more attention to improve students' transversal competences for their future jobs (I.SF2.EN).

TVET colleges need to organize more extra-activities and cooperate with many good enterprises in order that students can experience and study more (I.ST1.CL3). They should give students more chance to exchange graduates who succeed in life/business (I.ST2.CL3).
Additionally, it is necessary to have an official policy from the government in supporting human resources as well as financing from the managing board (LD1.CL1, LD1.CL2). Strengthening the knowledge as well as the skills for the teachers in T.S is of importance.

In short, T.S in vocational education and training play a key factor in ensuring people an effective contribution to their lives and communities. Applying T.S in teaching and learning at colleges aims at equipping students living and working skills that help them more self-confident and have better jobs. This paper concludes that T.S can be found in education and need to impart in curriculum and training policies. However, many potential difficulties in introducing T.S at the college level still exist. Teachers' training courses in the region or in other countries will cost stakeholders time and fund (I.LD1.CL3). After training, experienced employees tend to move to another company with higher salary. Additionally, there are several elements including facilities, curriculum, pedagogies, and assessment that all influence effective and efficient policy implementation. Teachers play an important role in teaching and fostering students' T.S, but there are not any specific guidance or policies for them. Teachers face lots of challenges and time to incorporate T.S in teaching practices. The lack of experienced teachers, pedagogies, learning environment and adequate assessment is also a big gap in education policies and practices. However, with the increasing industry development, teachers, and students should be supported adequately in teaching and learning transversal competences. The closer collaboration and exchange between TVET institutions and industry should be fostered. The flexible career pathways between industry and the trainer profession in TVET institutions should be promoted. Finally, teachers should be encouraged to work temporarily in companies to update their vocational competencies.

\section{Acknowledgements}

We would like to express our deepest appreciation to all those who provided us the possibility to complete this research report. A special gratitude is given to the UNESCO Asia and Pacific Regional Bureau for Education (UNESCO Bangkok. Without their support, our research report could not reach this present standard.

Furthermore, we would also like to acknowledge with much appreciation the crucial role of the stakeholders of 5 vocational colleges in Central Vietnam who gave the permission to interview and share the necessary materials to complete the research report.

\section{References}

[1] UNESCO. (2012). Youth and Skills - Putting Education to Work. EFA Global Monitoring Report 2012. Retrieved 26/9/2014: http://unesdoc.unesco.org/ images/0021/002180/218003e.pdf. 
[2] Altbach, P. G. (2002). Knowledge and education as international commodities: The collapse of the common good. International Higher Education: Reflections on Policy and Practice. Retrieved 08/1/2015, 2015, from http://www.bc.edu/content/dam/files/research_sites/cihe/pubs/ Altbach_2006_Intl_HigherEd.pdf.

[3] Hager, P. (2003). Changing Pedagogy: Productive Learning: University of Technology, OVAL.

[4] Dao. V. H. (2014). Quản lý đào tạo theo năng lục thục hiện nghề kỹ thuật xây dựng ở các trường cao đăng xây dưng. (Doctor), Vien Khoa hoc Giao duc Viet Nam. (62 1405 14).

[5] Tran Thi Tuyet (2012). Graduate employability: Interpretation versus expectation. In N. Brown, S. M. Jones \& A. Adam (Eds.), Research and development in higher education: Connections in higher education, Vol. 35 (pp. 317-325). Hobart, Tasmania: HERDSA.

[6] Ho, T. H. T. ( 2014). Vocational Education and Training in Vietnam in Tran, L., Margison, S. et al (Eds). Higher Education in Vietnam: Flexibility, mobility and practicability. Palgrave Macmillan Publisher.

[7] Le, H. M., \& Fünfhaus, A. (2014). Web-supported pedagogies for self-directed learning and transferable skills in Vietnam. TVET@Asia (3), 1-18.

[8] World Bank (2013), Vietnam: Skilling up Vietnam: Preparing the workforce for a modern market economy. Vietnam Development Report 2014. Retrieved 26/9/2014: http://www-wds.worldbank.org/external/default/WDSContent Server/WDSP/IB/2013/11/26/000461832_20131126115640/R endered/PDF/829400AR0P13040Box0379879B00PUBLIC0. pdf.

[9] General Statistics Office -GSO. (2018). Báo cáo Điều tra Lao động việc làm Quý I 2018. Retrieved 10/4/2018: https://gso.gov.vn/default.aspx?tabid=512\&idmid=5\&ItemID $=18992$.

[10] Mac, V. T. (2011). Labour market situation in Vietnam and the international cooperation for vocational training. Retrieved 25/9/2014

http://buenaspracticas.stps.gob.mx/buenaspracticas/pdf 2011/ 14_Labour_market_situation_Viet.pdf.

[11] General Statistics Office -GSO. (2014). Báo cáo Điều tra Lao động việc làm năm 2014. Retrieved 25/5/2017: https://gso.gov.vn/default.aspx?tabid=512\&idmid=5\&ItemID $=15113$.

[12] Nguyen, Dat. (2018). Vietnamese labor productivity among lowest in Asia despite growth: report. Retrieved 4 August 2018. https://e.vnexpress.net/news/business/data-speaks/vietnameselabor-productivity-among-lowest-in-asia-despite-growth-repor t-3747080.html.

[13] General Statistics Office-GSO. (2017). Báo cáo Điều tra Lao động việc làm quý IV 2017. Retrieved 05/4/2018: https://gso.gov.vn/default.aspx?tabid=512\&idmid=5\&ItemID $=18832$.

[14] Powell, M. \& Lindsay, I. (2010). Skills development strategies for rapid growth and development: The East Asian economic miracle. The Center for Employment Initiative, Retrieved 24/6/2014 www.cei-international.org.

[15] GDVT, G. D. o. V. T. (2012). Vietnamese TVET Background Paper. Hanoi, Vietnam.

[16] MOET. (2011). TVET in Vietnam and challenges. Retrieved 13/9/2011, https://http://www.voced.edu.au/content/ngv\%3A2494.

[17] MOET. (2014). Thông tư số 04/2014/TT-BGDĐT của Bộ Giáo dục và Đào tạo: Ban hành Quy định Quản lý hoạt động giáo dục kỹ năng sống và hoạt động giáo dục ngoài giờ chính khóa. http://vanban.chinhphu.vn/portal/page/portal/chinhphu/hethon gvanban?class_id $=1 \&$ page $=3 \&$ mode $=$ detail\&document_id $=$ 172757.

[18] World Bank (2013) Vietnam's Workforce Needs New Skills for A Continued Economic Modernization, Says Vietnam Development Report 2014. Retrieved 26/9/2014: http://www.worldbank.org/en/news/press-release/2013/11/29/ vietnams-workforce-needs-new-skills-for-a-continued-econom ic-modernization-says-vietnam-development-report2014.

[19] Lucas, B., Spencer, E., \& Claxton, G. (2012). How to Teach Vocational Education: A Theory of Vocational Pedagogy (December 2012 ed.): City \& Guids Center for Skill Developmeny-University of Winchester.

[20] United Nations Educational, Scientific and Cultural Organization- UNESCO (2014). Technical and Vocational Education and Training (TVET): Policy Implications, Asia-Pacific Education System Review. 8. Thailand.

[21] Tam, A., and Trzmiel, B. (2017). Transversal Skills as a Missing Link Between Schools and Work: Experiences from the Asia Pacific Region. in M., Pawlova; J. CK., Lee; and R., Maclean, R. (Eds). Transitions to Post-School Life: Responsiveness to Individual, Social and Economic Needs. (pp 35-50). Springer.

[22] Sukhan, S. S. (2012). Pedagogy of the dispossessed: Exploring the social environment of tecnical/vocational teacher education ( $\mathrm{PhD}$ Desertation), York University, Canada.

[23] Dumont, H., Istance, D., \& Benavides, F. (2010). The Nature of Learning: Using research to inspice practice. OECD: OECD.

[24] Hannafin, M. J., \& Land, S. M. (1997). The foundations and assumptions of technology-enhanced student-centered learning environments. Instructional Science, 2 (25), 167-202.

[25] Garrison, C., Chandler, D., \& Ehringhaus, M. (2011). Effective Classroom Assessment: Linking Assessment with Instruction. Retrieved 15 January 2015, 2015, from http://schools.nyc.gov/NR/rdonlyres/33148188-6FB5-4593-A 8DF-8EAB8CA002AA/0/2010_11_Formative_Summative_A ssessment.pdf.

[26] William, D., \& Leahy, S. (2007). A theoretical foundation for formative assessment. In H. J. McMillan (Ed.), Formative Classroom Assessment: Theory into Practice (pp. 29-42). New York: Teachers College Press.

[27] Bridges, D. (1992) Transferable skills: a philosophical perspective. Studies in Higher Education, 18 (1): 43-51. 